\title{
COMPLEMENTARY AND ALTERNATIVE MEDICINES: THE HERBAL MALE CONTRACEPTIVES
}

\author{
Fanuel Lampiao \\ Physiology Department, College of Medicine, P.O. Box 360, Blantyre 3, Malawi. \\ Email: flampiao@medcol.mw
}

\begin{abstract}
For a very long time, family planning methods have paid little attention to the needs of men, but instead focused primarily on women. A bulk of contraceptives on the market today is women oriented. Probably, many providers assume that women have the greatest stake and interest as far as family planning is concerned. Worst still, there is a misconception that men are indifferent or even stand in opposition to family planning. The consequences of this long neglect of developing acceptable and reliable male contraceptives in poor developing countries has been lack of or less participation of males in family planning. Recently, it has come apparent that neglecting men in matters of family planning is a losing strategy with adverse consequences for both men and women. As Africa is grappling with rapid population growth, it is now recognized that giving attention to females only can not solve the problem.
\end{abstract}

Key words: Contraceptives, herbal medicines, fertility, family planning

\section{Introduction}

There is a great concern of population growth worldwide such that several methods are being used to reduce both men and women total fertility rate, especially in developing countries. Overpopulation continues to be a significant contributor to environmental degradation and human suffering worldwide. Much of the current growth in the population is unintended. It is estimated that half of all conceptions are unplanned and half of the resulting pregnancies are undesired (Henshaw, 1998). In most cases, half of the unintended pregnancies are due to failure to use contraception, and the other half to difficulties with contraceptive use or method failure (Finer and Henshaw, 2003). In poor nations, contraception use is further limited by restricted access to many available methods, both economically and culturally. Undesired pregnancies result in unwanted children who suffer disproportionately from poverty and neglect (Besculides and Laraque, 2004; Goto et al., 2006).

Women have a wide range of contraceptive choices. Research and family planning organizations have for a long time focused upon female methods of contraception because women bear a disproportionate portion of the health and economic consequences of childbearing and rearing. Consequently, women have many contraceptive choices, ranging from daily oral medications to intrauterine devices implanted every 5 years to sterilization.

The consequences of this long neglect of developing acceptable and reliable male contraceptives in poor developing countries has been lack of or less participation of males in family planning. Recently, it has come apparent that neglecting men in matters of family planning is a losing strategy with adverse consequences for both men and women (Ringheim, 1993).

There are many references to plants in literature with antifertility properties. This review will highlight some of the herbs which could potentially be developed into a reversible male contraceptive as well as discuss difficulties of developing such a contraceptive.

\section{Need for male contraception}

There are varying reasons why couples practice contraception. The reasons vary from postponing childbearing, spacing births and limiting family size as well as to have absolute freedom from childbearing (Ringheim, 1993). These needs usually vary depending on the type of relationship, purpose of contraception and the age of the couple. The current available methods on the market for men and women do not adequately meet the varied and changing personal needs of couples in their reproductive lives and in the widely different geographical, cultural, religious and service delivery settings around the world (Besculides and Laraque, 2004). While increasing the choice available to either partner will ensure the wider availability of safe and effective means for fertility regulation, the shortcomings of currently few available male contraceptive methods are a major barrier to the involvement of men in family planning. Current research into male contraceptives will potentially increase the equitability of family planning between males and females. This would greatly address issues of population growth and its related detrimental effects on the environment. 


\section{Male contraceptive options}

Currently researchers have focused their investigations on three general categories of male contraceptives. The first method involves the physical blockage of the vas deferens, the channel that carries sperm from the epididymis to the ejaculatory duct. The second uses heat to induce temporary sterility. The third involves medication to halt sperm production.

\section{Vasectomy}

Male vasectomy is the most effective of male methods of contraception currently available. Despite its effectiveness, there are two major disadvantages that make it unattractive to many men as an option for contraception. The first is the psychological component relating to surgery. Although vasectomies are relatively non-invasive, when compared to taking a pill the procedure seems drastic. The second reason is that, although vasectomies are reversible, the rate of return to normal fertility is only about $40 \%$.

\section{Condoms}

Male latex condoms offer very effective prevention from unplanned pregnancy and HIVIAIDS infection. A significant drawback to condoms is their poor long-term compliance, with more than half of users reporting inconsistent use with every act of intercourse (Mosher and Pratt, 1993). In addition, many men dislike condoms because they feel condoms diminish sexual pleasure (Grady et al., 1993), again hampering consistent usage. However, even when used correctly, condom breakage and slippage are not infrequent, occurring in up to 2-8\% of cases (Gallo et al., 2003; Macaluso et al., 1999; Potter and de Villemeur, 2003; Steiner et al., 2003; Walsh et al., 2003).

\section{An ideal male contraceptive}

Development of effective, safe and acceptable male contraceptive is challenging. For it to be embraced by males it must have no effect on libido or sexual function as well as it must be reversible. The approach to development of male contraceptive can be either to inhibit the production of sperm (spermatogenesis), interference with sperm function and structure, interruption of sperm transport, interruption of sperm deposition or prevention of sperm-egg interaction. Recent research efforts have demonstrated high efficacy rates for hormonally based male contraceptives. Current barriers to expanded use include limited delivery methods and perceived regulatory obstacles, which stymie introduction to the marketplace (Page et al., 2008). Probably, advances in herbal orally delivered contraceptives may cause optimism that these hurdles may be overcome. Historically, efforts in male contraception have lagged substantially behind development of female contraceptives due to the complexity of the male reproductive system, social/behavioral aspects and economic considerations. The last reasoning is based on the assumptions that (a) due to availability of safe and effective female contraceptives, male methods are unnecessary; (b) men are unwilling to take contraceptive pills or injections; and (c) men will not adhere to contraceptive drug regimens as careful as do women. These suppositions are in contrast to studies conducted in more than 9000 men in nine countries on four continents (Heinemann et al., 2005). In these studies, men of all nationalities and religions indicated a willingness to use a male contraceptive if a safe, effective product was available.

\section{The herbal male contraceptive}

Finding an oral herbal contraceptive would allow couples control their fertility without consulting a health worker, which in turn would likely markedly increase the number of couples practicing family planning. Other advantages of such a contraceptive would include the familiarity rural people in Africa have with herbal medicines, the fewer side effects associated with herbal preparations, their ready availability from local sources, and protection of privacy.

Africa is a continent endowed with an enormous wealth of plant resources. These plants have been used for several generations in traditional medicine for the treatment of different ailments. Although a few research publications are available on the constituents and biological activity of some of these medicinal plants, the development of therapeutic agents from these medicinal plants has remained a somewhat neglected subject. The study of medicinal plants in Africa has not been taken as seriously or documented as fully as in other traditional societies, such as the Indian and Chinese. Our knowledge of African medicinal plants used for reproductive purposes is rather limited and the little available information is often fragmented. Very few studies in Africa and other developing countries have focused on herbal male contraceptives. Most of the studies done are on aphrodisiacs which aim at improving the male fertility (Kamchouing et al., 2002; Watcho et al., 2004; Lampiao et al., 2008). These studies have reported the efficacy of herbal aphrodisiacs such as Mondia whitei on improving the male reproductive function. Most of the literature on herbal male contraceptives is coming from the Chinese. Zheng et al., (1995) reported the antifertility actions of an extract from Tripterygium wilfordii both in male rats and in men. This plant's functional mechanism was by inhibiting the basic nuclear protein turnover of late spermatids, delayed spermiation, sperm head-tail separation and microfilament and membrane damage. 
Table 1: Summary of plants with antifertility effects in different animal models.

\begin{tabular}{|c|c|c|c|}
\hline Plant Name & Animal Model & Antifertility Effects & Reference \\
\hline Vinca rosea & Rats & $\begin{array}{l}\text { Leaf extract shown to be } \\
\text { antispermatogenic and } \\
\text { antiandrogenic. }\end{array}$ & $\begin{array}{l}\text { Murugavel and Akbarsha, } \\
1991 .\end{array}$ \\
\hline \multirow[t]{3}{*}{ Carica papaya } & Albino rats & $\begin{array}{l}\text { Crude ripe paw paw seeds caused } \\
\text { degeneration of germinal } \\
\text { epithelium and germ cells, } \\
\text { reduction in Leydig cell number } \\
\text { and vacuoles in the tubules. }\end{array}$ & Udoh and Kehinde, 1999. \\
\hline & Monkeys & $\begin{array}{l}\text { Chloroform extract of Carica } \\
\text { papaya seeds caused decreased } \\
\text { sperm concentration, poor } \\
\text { morphology, vacuolization in the } \\
\text { cytoplasm of Sertoli cells }\end{array}$ & Lohiya et al., 2002. \\
\hline & Rabbit and human & $\begin{array}{l}\text { Extract of leaves and stem caused } \\
\text { a drop in sperm motility and } \mathrm{pH} \text { of } \\
\text { semen }\end{array}$ & Nassar, 1979. \\
\hline Ecballium ellaterum & Human & $\begin{array}{l}\text { Root bark extract reduced sperm } \\
\text { motility and concentration. }\end{array}$ & Qian, 1987. \\
\hline \multirow[t]{3}{*}{ Tripterygium } & Rats & $\begin{array}{l}\text { Induced complete infertility by } \\
\text { acting on epididymal sperm with } \\
\text { minimal effects on the testes. }\end{array}$ & Lue et al., 1998. \\
\hline & Human & $\begin{array}{l}\text { Steroidal alkaloid caused } \\
\text { disruptive changes in the } \\
\text { acrosomal membrane of human } \\
\text { sperm and arrested sperm motility. }\end{array}$ & Kanwar et al., 1988. \\
\hline & Dogs & $\begin{array}{l}\text { Oral administration decreased the } \\
\text { epithelial cell height of the cauda } \\
\text { epididymides. }\end{array}$ & Gupta and Dixit, 2002. \\
\hline \multirow{3}{*}{$\begin{array}{l}\text { Solanum } \\
\text { xanthocarpum }\end{array}$} & Rats & $\begin{array}{l}\text { Leaf extract affects the structure } \\
\text { and function of testis and } \\
\text { spermatozoa. }\end{array}$ & Shaikh et al., 1993. \\
\hline & & $\begin{array}{l}\text { Leaf extract caused } \\
\text { antiandrogenic properties. }\end{array}$ & Kasturi et al., 1995. \\
\hline & & $\begin{array}{l}\text { Ethanol extract of bark and flowers } \\
\text { induced reversible infertility. }\end{array}$ & Dixit et al., 1992. \\
\hline Azadirachta indica & Rats & $\begin{array}{l}\text { Seed steroidal fraction caused } \\
\text { reduction in testicular weight, } \\
\text { sperm count and degeneration in } \\
\text { later stages of spermatogenesis. }\end{array}$ & $\begin{array}{l}\text { Kulshreshtha and Mathur, } \\
1990 .\end{array}$ \\
\hline Abrus precatorius & & $\begin{array}{l}\text { Seed extract caused impairment in } \\
\text { perm concentration and motility. }\end{array}$ & Ratnasooriya et al., 1991. \\
\hline
\end{tabular}

Even though traditional medicines used as contraceptives have a long history in Africa, very few studies have been conducted to confirm their efficacy as well as establish their mechanisms of action. Some few studies in animal models have shown that herbs such as Balanites roxburghii (Rao et al., 1997a), Phyllanthus amarus (Rao et al., 1997b) and Carica papaya seeds (Chinoy et al., 1995) have antispermatogenic effects in male animal models. Table 1 summarizes some of the plants that have been reported to exert antifertility effects in different animal models. Some selected plants with proven antifertility effect are discussed below. 


\section{Carica papaya}

The effect of Carica papaya seed extract inducing sterility in male rats has been reported in literature (Das, 1980). Chinoy et al. (1995) reported the contraceptive efficacy of orally administered aqueous extracts of papaya seeds in male albino rats. The extract had a post-testicular action and the effects were reported to be reversible upon withdrawal of treatment. Furthermore, Lohiya et al. (1992) also reported the contraceptive effect of a crude chloroform extract of papaya seeds in male albino rats.

\section{Tripterygium wilfordii}

This is a perennial twining vine growing densely on the hill slopes in the southern part of China. This herb has been used in traditional Chinese medicine for the treatment of fever, edema and carbuncle for a very long time. Its powdered roots are also used as insecticides. Recently the plant has been used for the treatment of rheumatoid arthritis, chronic nephritis, chronic hepatitis, thrombocytopenic purpura, ankylosing spodylitis and many skin diseases (Qian, 1987). This plant is commercial available as tablets, each containing $10 \mathrm{mg}$ of extract, and the recommended adult dose is $60-90 \mathrm{mg} / \mathrm{day}$.

The hint that Tripterygium wilfordii possesses male antifertility effects was discovered when rheumatoid arthritis patients treated with the decoction of Tripterygium wilfordii for a total of 2-56 months presented with necrospermia or azoospermia (Yu, 1983). Later, it was shown that in Wistar rats fed with laboratory chow mixed with toxic doses of Tripterygium wilfordii, the seminiferous epithelium was damaged with a decrease in the serum level of testosterone (Zheng et al., 1985). This led to worldwide interest in this herb and reports of a sharp decrease in the epididymal sperm motility and moderate decrease in the sperm concentration in rats have been reported (Qian et al., 1986). These studies demonstrated that Tripterygium wilfordii has antifertility effects in both male human and rats.

\section{Azadirachta indica}

The administration of a leaf extract of this plant has been reported to affect the structure and function of the testis and spermatozoa in male rats (Shaikh et al., 1993). Some studies have also reported the antiandrogenic effects of Azidirachta indica leaves in male rats (Kasturi et al., 1995). The ethanol extract of its bark and flowers has been shown to induce reversible infertility in male rats by interfering with spermiogenesis at the late spermatids level (Dixit et al., 1992).

Many African countries have set up research facilities to study plant medicines with the hope that the plants and their derived compound may be utilized for drug production. There is now a wide belief that standardization of plants should be given priority so that the near end products, free of toxic material can be dispensed to patients (Msonthi, 1987). This alternative route is shorter and much more meaningful since it takes a very long time for a drug to be developed from a medicinal plant.

\section{Drawbacks for developing herbal contraceptive}

One of the drawback researchers investigating potential herbs that could be developed into a male contraceptive is the non-reproducibility of published data from which useful leads might develop. Some researchers report efficacy of a plant while other report no activity of the same plant. The other problem is that crude extracts of herbal contraceptives used by humans may be ineffective in animal models. The solution to this is to investigate the efficacy of these herbs in humans themselves, after ascertaining their safety in animal models. There is also a need to record the conditions under which the plants are used by indigenous people, including the time and place of collection, proper botanical authentication, as well as schedule of administration.

\section{Conclusion}

The investigation about the function and mechanisms of action of traditional herbs used in Africa as male contraceptives is becoming increasingly urgent because of the less participation of males in family planning as well as the rapid loss of the natural habitat of some of these plants. Some of them become extinct before they are even documented. Scientific evidence backing their use as potent male contraceptives will probably stimulate interest to safeguard their survival.

\section{References}

1. Besculides, M., Laraque, F. (2004). Unintended pregnancy among the urban poor. J. Urban Health 81: $340-$ 348.

2. Chinoy, N.J., D'Souza, J.M., Padman, P. (1995). Contraceptive efficacy of Carica papaya seed extract in male mice (Mus musculus). Phytother. Res 9: 30-36.

3. Das, R.P. (1980). Effects of papaya seed on the genital organs and fertility of male rats. Indian J. Exp. Biol. 18: $408-409$.

4. Dixit, V.P., Jain, P., Purohit, A.K. (1992). Medicinal uses of neem (Azadirachta indica) in fertility regulation, diabetes and atherosclerosis. Rec. Adv. Med. Aromatic Spice Crops 2: 463-471. 
5. Finer, L.B., Henshaw, S.K. (2003). Abortion incidences and services in the United States in 2000. Pespect. Sex. Reprod. Health 35: 6-15.

6. Gallo, M.F., Grimes, D.A., Schulz, K.F. (2003). Nonlatex vs. latex male condoms for contraception: a systematic review of randomized controlled trials. Contraception 68: 319-326.

7. Goto, A., Yasumura, S., Yabe, J., Reich, M.R. (2006). Addressing Japan's fertility decline: influences of unintended pregnancy on child rearing. Reprod. Health Matters 14: 191-200.

8. Grady, W.R., Klepinger, D.H., Billy, J.O., Tanfer, K. (1993). Condom characteristics: the perception and preferences of men in the United States. Fam. Plann. Perspect 25: 67-73.

9. Gupta, R.S., Dixit, V.P. (2002). Effects of short term treatment of salasodine on cauda epididymis in dogs. Indian J. Exp. Biol. 40: 169-173.

10. Heinemann, K., Saad, F., Wiesemes, M., White, S., Heinemann, L. (2005). Attitudes toward male fertility control: results of a multinational survey on four continents. Hum. Reprod. 20: 549-556.

11. Henshaw, S.K. Unintended pregnany in the United States. (1998). Fam. Plann. Perspect. 30: 24-29.

12. Kamtchouing, P., Mbongue, G.Y., Dimo, T., Jatsa, H.B. (2002). Evaluation of androgenic activity of Zingiber officinale and Pentadiplandra brazzeana in male rats. Asian J. Androl. 4: 299-301.

13. Kanwar, U., Batla, A., Ranga, A., Sanyal, S.N. (1988). Effect of solasodine on morphology, motility and glycolytic enzymes of buffalo bull spermatozoa. Indian J. Exp. Biol. 26: 941-944.

14. Kasturi, M., Manivannan, B., Nazeer Ahmed, R., Shaikh, P.D., Pathan, K.M. (1995). Changes in epididymal structure and function of albino rat treated with Azadirachta indica leaves. Indian J. Exp. Biol. 33: 725-729.

15. Kulshreshtha, S.S., Mathur, R.S. (1990). Effect of steroidal fraction of seeds of Abrus precatorius Linn. On rat testis. Indian J. Exp. Biol. 28: 752-756.

16. Lampiao, F., Krom, D., Du Plessis, S.S. (2008). The in vitro effect of Mondia whitei on human sperm motility parameters. Phytother. Res. 22: 1272-1273.

17. Lohiya, N.K., Manivannan, B., Mishra, P.K. (2002). Chloroform extract of Carica papaya seeds induces long-term reversible azoospermia in Langur monkeys. Asian J. Androl. 4: 17-26.

18. Lohiya, N.K., Ravi, B.G. (1992). Antifertility investigations on the crude chloroform extract of Carica papaya seeds in male albino rats. Indian J. Exp. Biol. 30: 1051-1055.

19. Lue, Y., Sinha Hikim, A.P., Wang, C. (1998). Triptolide: a potential male contraceptive. J. Androl. 19: 479-486

20. Macaluso, M., Kelaghan, J., Artz, L., Austin, H., Fleenor, M., Hook, E.W., Valappil, T. (1999). Mechanical failure of the latex condom in a cohort of women at high STD risk. Sex. Transm. Dis. 26: 450-458.

21. Mosher, W.D., Pratt, W.F. (1993). AIDS-related behaviour among women 15-44 years of age: United States, 1988 and 1990. Adv. Data 239: 1-15.

22. Msonthi, J.D. (1987). Herbs of medicinal value in Malawi - a potential for drug formulation. Proceedings of a National Forestry Research Symposium, p146-161.

23. Murugavel, T., Arkbarsha, M.A. (1991). Antispermatogenic effect of Vinca rosea Linn. Indian J. Exp. Biol. 29: 810-812.

24. Nassar, M.F. (1979). Male oral contraceptive. United States Patent 4: 148-892.

25. Page, S.T., Amory, J.K., Bremner, W.J. (2008). Advances in male contraception. Endocrine Reviews 29: 465-493.

26. Potter, W.D., de Villemuer, M. (2003). Clinical breakage, slippage and acceptability of a new commercial polyurethane condom: a randomized controlled study. Contraception 68: 39-45.

27. Qian, S.Z. (1987). Tripterygium wilfordii: a Chinese herb effective in male fertility regulation. Contraception 36: 247-263.

28. Qian, S.Z., Zhong, C.Q., Xu, Y. (1986). Effect of Tripterygium wilfordii on the fertility of rats. Contraception 33: 105-110.

29. Rao, M.V., Shah, K.D., Rajani, M. (1997a). Contraceptive effects of Phyllanthus amarus extract in the male mouse. Phytother. Res. 11: 594-596.

30. Rao, M.V., Shah, K.D., Rajani, M. (1997b). Contraceptive efficacy of Balanites roxburghii pericarp extract in male mice (Mus musculus). Phytother. Res. 11: 469-471.

31. Ratnasooriya, W.D., Amarasekera, A.S., Perera, N.S.D., Premkumari, G.A.S. (1991). Sperm antimotility properties of a seed extract of Abrus precatorius. J. Ethnopharmacol. 38: 85-90.

32. Ringheim, K. (1993). Factors that determine the prevalence of use of contraceptive methods for men. Studies in Family Planning 24: 87-99.

33. Shaikh, P.D., Manivannan, B., Pathan, K.M., Nazeer Ahmed. (1993). Antispermatic activity of Azadirachta indica leaves in albino rats. Curr. Sci. 64: 688-689.

34. Steiner, M.J., Dominik, R., Rountree, R.W., Nanda, K., Dorfflinger, L.J. (2003). Contraceptive effectiveness of polyurethane condom and a latex condom: a randomized controlled trial. Obstet. Gynecol. 101: 539-547.

35. Udoh, P., Kehinde, A. (1999). Studies on the antifertility effect of paw paw seeds (Carica papaya) on the gonads of male albino rats. Phytother. Res. 13: 226-228.

36. Walsh, T.L., Frezieres, R.G., Peacock, K., Nelson, A.L., Clark, V.A., Berstein, L. (2003). Evaluation of the efficacy of nonlatex condom: results from a randomized, controlled clinical trial. Perspect. Sex. Reprod. Health 35: 79-86.

37. Watcho, P., Kamtouing, P., Sokeng, S.D., Moundipa, P.F., Tantchou, J., Essame, J.L., Koueta, N. (2004). Androgenic effect of Mondia whitei roots in male rats. Asian J. Androl. 6: 269-272. 
38. Yu, D.Y. (1983). One hundred and forty-four cases of rheumatoid arthritis treated with Tripterygium wilfordii. J Traditional Chinese Med. 3: 125-129.

39. Zheng, J.R., Fang, J.L., Xu, L.F. (1985). Effect of total glycosides of $T$. wilfordii on reproductive organs of male rats. Acta Academicae Medicae Sinicae 7: 256-259.

40. Zheng, Q., Ye, X., Wei, Z. (1995). Recent progress in research on Triterygium: a male antifertility plant. Contraception 51: 121-129. 